\title{
HIP PROSTHESIS BIOMATERIALS: A CHALLENGE IN PREVENTION OF BIOFILM FORMATION
}

\author{
BIOMATERIAIS DE PRÓTESES DE QUADRIL: UM DESAFIO NA PREVENÇÃO DA \\ FORMAÇÃO DE BIOFILME
}

\begin{abstract}
Daniella Maia MARQUES ${ }^{1}$; Álvaro Francisco Lopes de SOUSA ${ }^{2}$; Paula Regina de Souza HERMANN ${ }^{3}$; Denise de ANDRADE ${ }^{4}$; Evandro WATANABE ${ }^{5}$

1. Enfermeira e Doutoranda pelo Programa de Pós-Graduação em Enfermagem Fundamental da Escola de Enfermagem de Ribeirão Preto, Universidade de São Paulo - USP, Ribeirão Preto, SP, Brasil. daniella.marques@ usp.br; 2. Enfermeiro pela Universidade Federal do Piauí - UFPI, Teresina, PI, Brasil e Doutorando pelo Programa de Pós-Graduação em Enfermagem Fundamental da Escola de Enfermagem de Ribeirão Preto, Universidade de São Paulo - USP, Ribeirão Preto, SP, Brasil; 3. Enfermeira, Doutora e Professora Adjunta da Faculdade de Ceilândia, Universidade de Brasília - UnB, Brasília, DF, Brasil; 4. Enfermeira, Doutora e Professora Associada do Departamento de Enfermagem Geral e Especializada da Escola de Enfermagem de Ribeirão Preto - USP, Ribeirão Preto, SP, Brasil; 5. Farmacêutico-Bioquímico, Doutor e Professor Associado do Departamento de Odontologia Restauradora da Faculdade de Odontologia de Ribeirão Preto - USP, Ribeirão Preto, SP, Brasil.
\end{abstract}

\begin{abstract}
The objective of this study was to identify the scientific evidences regarding biofilm formation prevention on hip prosthesis biomaterials. It's an integrative review that aims to answer the following question: what are the scientific evidences regarding biofilm formation prevention on hip prosthesis biomaterials? The search was performed on PubMed portal and on databases: Web of Science, Embase, Cochrane, CINAHL and LILACS. Primary studies about the topic published online up until November 2017 in English, Spanish and Portuguese are included. Among 16 primary studies, $81.25 \%$ were in vitro experimental studies, in which polyethylene showed a higher biofilm formation than metallic biomaterials and polymethylmethacrylate. Among clinical studies, Staphylococcus epidermidis and Staphylococcus aureus were isolated in most of joint prosthesis components. New acylase-containing polyurethane coatings, silver-zirconium carbonitride films, bioactive gentamicin, biodegradable gentamicin-hydroxyapatite, vancomycin, titanium-silicon-carbonoxygen-nitrogen films and cross-linked polyethylene combined with vitamin E and a poly(2-methacryloyloxyethyl phosphorylcholine) layer were developed to prevent biofilm formation. Moreover, cobalt-chromium (Co-Cr) ions inhibited bacterial growth, and cobalt-chromium particles reduced biofilm development. The biomaterials that presented properties against biofilm formation were: bioactive gentamicin, biodegradable gentamicin-hydroxyapatite, vancomycin, acylasecontaining polyurethane, cross-linked polyethylene combined with vitamin E-blended and a poly(2-methacryloyloxyethyl phosphorylcholine) layer, silver-zirconium carbonitride films and titanium-silicon-carbon-oxygen-nitrogen films. Moreover, the $\mathrm{Co}-\mathrm{Cr}$ particles released from metallic joint prosthesis showed higher antibiofilm activity than Co-Cr ions.
\end{abstract}

KEYWORDS: Biofilms. Hip Prostheses. Hip Arthroplasty.

\section{INTRODUCTION}

Hip arthroplasty enabled mobility, quality of life and pain relief for patients with musculoskeletal disorders (LAMAGNI, 2014). However, the increase of these revision surgeries, even with the improvement of techniques and progress in prosthesis design and composition, is a factor that has generated problems and challenges in this field (BOZIC et al., 2015).

Only in the United States, the number of total hip arthroplasties (THA) doubled in four years, with nearly 260,000 surgeries done in 2004 and 423,000 in 2008 (VON RECUM, 1998; PUCKETT et al., 2010; WU et al., 2011).

This procedure is liable to complications, since the infection related to implant is considered a major cause of prosthesis restricted movements and reduced durability (BOZIC et al., 2009).
Biofilm formation occurs with microbial adhesion to implant surface and production of a polymeric extracellular matrix (ECM) composed by proteins, polysaccharides and genetic material. The ECM make biofilm sessile microorganisms resistant to antibiotics and inaccessible to the immune system in comparison to planktonic microbiota. The control of microbial adhesion can prevent biofilm formation with a contamination risk reduction (LEONHARDT; OLSSON; DAHLEN, 1995; VON RECUM, 1998; DONLAN, 2001; WASELAU, 2002; CAMPOCCIA; MONTANARO; ARCIOLA, 2006; FRÖJD, 2010; PUCKETT et al., 2010; WU et al., 2011).

Biofilm formation on medical devices and joint infection must be prevented because they are serious complications that can lead to patient immobilization, prolonged hospitalizations, functional and emotional morbidity as well as high 
costs to the health system (KLOUCHE; SARIALI; MAMOUDY, 2010).

At present, the treatment of infections associated with hip arthroplasty causes unnecessary risks to patient and additional costs to health service because it consists of removal and replacement of prosthesis by a new device and antibiotictherapy. This way, biofilm formation prevention on orthopaedic devices is of utmost importance to reduce the chances of microbial adhesion. However, there is no formal and standardize recommendation by international headlines regarding what antimicrobial agents can be used, which make it difficult to apply these agents in clinical practice (SOUSA et al, 2017).

In this sense, the objective of this research was to identify scientific evidences regarding biofilm formation prevention on hip prosthesis biomaterials in order to contribute to the preventive and infection control measures as well as reduce the removal of the orthopaedic device.

\section{MATERIAL AND METHODS}

It's an integrative literature review. The adoption of the scientific method is based on the ability to summarize publications about a particular subject, obtaining a better understanding of the phenomenon to be investigated. For the search, the following guiding question was formulated: what are the scientific evidences regarding biofilm formation prevention on hip prosthesis biomaterials?

The search of primary studies was performed on PubMed portal and on databases: Web of Science, Cumulative Index to Nursing and Allied Health Literature (CINAHL), Literatura LatinoAmericana e do Caribe em Ciências da Saúde (LILACS), Embase and Cochrane. The search strategy was based on the usage of controlled descriptors "Biofilms", "Hip Prosthesis" and "Arthroplasty, Replacement, Hip", and boolean operators AND and OR.

The controlled descriptors (MeSH terms, CINAHL titles, DeCS and Emtree terms) and the keywords used according to the databases are assembled in chart 1.

Chart 1. Combination of controlled descriptors and keywords according to the portal and databases used on the search of primary studies.

\begin{tabular}{|c|c|}
\hline $\begin{array}{l}\text { Portal and } \\
\text { databases }\end{array}$ & Controlled descriptors and keywords \\
\hline $\begin{array}{l}\text { PubMed } \\
\text { Web of Science } \\
\text { Cochrane }\end{array}$ & $\begin{array}{l}\text { "Biofilms" OR "Biofilm" AND "Hip Prosthesis" OR "Hip Prostheses" OR } \\
\text { "Prostheses, Hip" OR "Prosthesis, Hip" OR "Femoral Head Prosthesis" OR } \\
\text { "Femoral Head Prostheses" OR "Prostheses, Femoral Head" OR "Prosthesis, } \\
\text { Femoral Head" AND “Arthroplasty, Replacement, Hip" OR "Arthroplasties, } \\
\text { Replacement, Hip" OR "Arthroplasty, Hip Replacement" OR "Hip Prosthesis } \\
\text { Implantation" OR "Hip Prosthesis Implantations" OR "Implantation, Hip } \\
\text { Prosthesis" OR "Implantations, Hip Prosthesis" OR "Prosthesis Implantation, } \\
\text { Hip" OR "Prosthesis Implantations, Hip" OR "Hip Replacement Arthroplasty" } \\
\text { OR "Replacement Arthroplasties, Hip" OR "Replacement Arthroplasty, Hip" } \\
\text { OR "Arthroplasties, Hip Replacement" OR "Hip Replacement Arthroplasties" } \\
\text { OR "Hip Replacement, Total" OR "Replacement, Total Hip" OR "Hip } \\
\text { Replacements, Total" OR "Replacements, Total Hip" OR "Total Hip } \\
\text { Replacements" OR "Total Hip Replacement" }\end{array}$ \\
\hline CINAHL & $\begin{array}{l}\text { "Biofilms" OR "Biofilm" AND “Arthroplasty, Replacement, Hip" OR "Hip } \\
\text { Prosthesis" OR "Arthroplasties, Replacement, Hip" OR “Arthroplasty, Hip } \\
\text { Replacement" OR "Hip Prosthesis Implantation" OR "Hip Prosthesis } \\
\text { Implantations" OR "Implantation, Hip Prosthesis" OR "Implantations, Hip } \\
\text { Prosthesis" OR "Prosthesis Implantation, Hip" OR "Prosthesis Implantations, } \\
\text { Hip" OR "Hip Replacement Arthroplasty" OR "Replacement Arthroplasties, } \\
\text { Hip" OR "Replacement Arthroplasty, Hip" OR "Arthroplasties, Hip } \\
\text { Replacement" OR "Hip Replacement Arthroplasties" OR "Hip Replacement, } \\
\text { Total" OR "Replacement, Total Hip" OR "Hip Replacements, Total" OR } \\
\text { "Replacements, Total Hip" OR "Total Hip Replacements" OR "Total Hip } \\
\text { Replacement" OR "Hip Prostheses" OR "Prostheses, Hip" OR "Prosthesis, } \\
\text { Hip" OR "Femoral Head Prosthesis" OR "Femoral Head Prostheses" OR } \\
\text { "Prostheses, Femoral Head" OR "Prosthesis, Femoral Head" }\end{array}$ \\
\hline
\end{tabular}




\begin{tabular}{|c|c|}
\hline LILACS & $\begin{array}{l}\text { "BIOFILME” AND “PROTESE DE QUADRIL” OR “ARTROPLASTIA DE } \\
\text { QUADRIL" }\end{array}$ \\
\hline Embase & 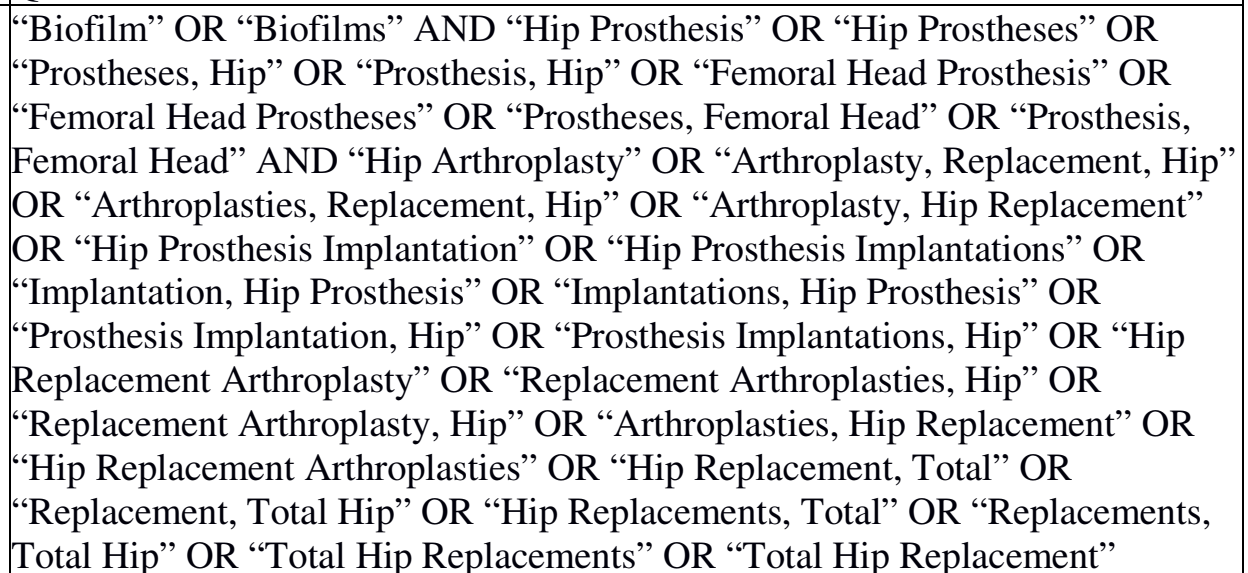 \\
\hline
\end{tabular}

The initial search recovered 237 scientific chart presents the search strategies used on the articles, in which 75 were duplicated studies, portal and databases for article selection (Figure 1). resulting in 162 primary studies (Table 1). The flow

Table 1. Distribution of scientific articles about biofilm implications on biomaterials used on hip prostheses, excluding duplicates, according to the portal and databases.

\begin{tabular}{cc}
\hline Databases & Number of articles \\
\hline PubMed & 94 \\
Web of Science & 22 \\
CINAHL & 3 \\
LILACS & 0 \\
Embase & 42 \\
Cochrane & 1 \\
Total articles & $\mathbf{1 6 2}$ \\
\hline
\end{tabular}

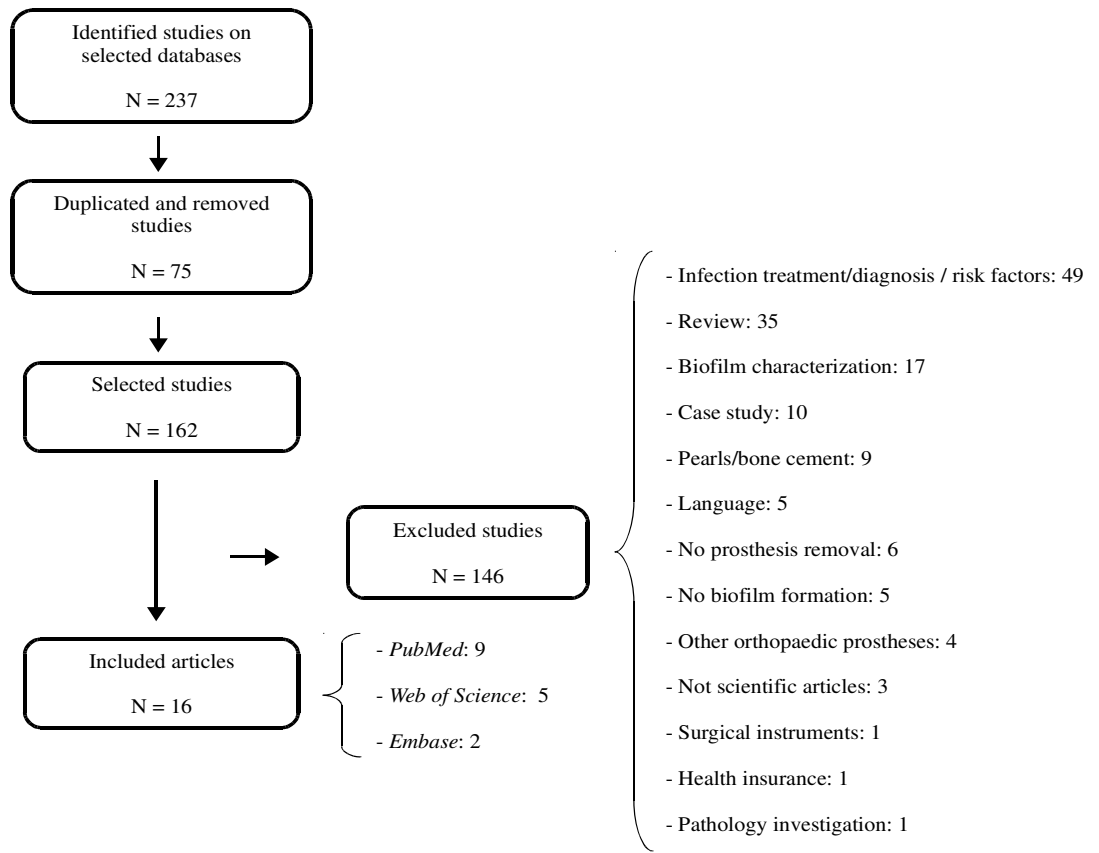

Figure 1. Flow chart for scientific article selection about biofilm implications on biomaterials used on hip prostheses on different portal and databases. 
Primary studies about the topic published online up until November 2017 in English, Spanish and Portuguese are included in this research. On the other hand, the scientific articles that characterized biofilm morphology and its nature, infection treatment/diagnosis, performed with pearls/bone cement, review articles and case study were excluded.

\section{RESULTS}

Thus, 16 studies were selected, of which $81.25 \%$ were laboratory / experimental in vitro, that is, studies that simulate biological conditions in the laboratory and don't involve human beings nor animals. According to publication year, there was a concentration of articles published in 2015 $(3 / 18.75 \%)$. Chart 2 presents a summary of the main information of each study.

Chart 2. Synopsis of publications about the biofilm implications on biomaterials used on hip prostheses.

\begin{tabular}{|c|c|c|c|c|}
\hline & Year & Study types & Strategies/resources & Main results \\
\hline 1 & 2003 & $\begin{array}{l}\text { In vitro } \\
\text { laboratory } \\
\text { experimental }\end{array}$ & $\begin{array}{l}\text { To determine if three } \\
\text { different titanium alloy } \\
\text { surfaces have effect in } \\
\text { biofilm formation }\end{array}$ & $\begin{array}{c}\text { There are differences among } \\
\text { Propionibacterium acnes, Staphylococcus } \\
\text { aureus and Staphylococcus epidermidis } \\
\text { biofilms on biomaterials }\end{array}$ \\
\hline 2 & 2004 & $\begin{array}{c}\text { In vitro } \\
\text { laboratory } \\
\text { experimental }\end{array}$ & $\begin{array}{l}\text { Method of vancomycin } \\
\text { tethering to titanium } \\
\text { surface }\end{array}$ & $\begin{array}{l}\text { Covalent linkage of vancomycin to titanium } \\
\text { surface usage preserved the bactericidal } \\
\text { activity and did not change the material surface }\end{array}$ \\
\hline 3 & 2007 & $\begin{array}{l}\text { Descriptive } \\
\text { analytical study }\end{array}$ & $\begin{array}{l}\text { Polyethylene }(\mathrm{PE}) \\
\text { ceramics; metal, } \\
\text { cemented, hybrid and } \\
\text { non-cemented surfaces }\end{array}$ & $\begin{array}{l}\text { Prostheses with polymeric materials showed } \\
\text { more microbial contamination }\end{array}$ \\
\hline 4 & 2009 & $\begin{array}{c}\text { In vitro } \\
\text { laboratory } \\
\text { experimental }\end{array}$ & $\begin{array}{l}\text { Cobalt-chromium } \\
\text { (Co-Cr) ions usage }\end{array}$ & $\begin{array}{l}\text { Metal ion concentrations inhibited bacterial } \\
\text { growth, but did not present bactericidal activity }\end{array}$ \\
\hline 5 & 2009 & $\begin{array}{c}\text { In vitro } \\
\text { laboratory } \\
\text { experimental }\end{array}$ & $\begin{array}{l}\text { Titanium-silicon-carbon- } \\
\text { oxygen-nitrogen } \\
\text { (Ti-Si-C-O-N) films }\end{array}$ & $\begin{array}{l}\text { The highest film concentration showed the } \\
\text { lowest biofilm formation, but the highest } \\
\text { degree of cytotoxicity }\end{array}$ \\
\hline 6 & 2010 & $\begin{array}{l}\text { In vitro } \\
\text { laboratory } \\
\text { experimental }\end{array}$ & $\begin{array}{l}\text { Nanocrystalline diamond } \\
\text { coating usage }\end{array}$ & $\begin{array}{l}\text { It did not inhibit the biofilm growth by } \\
\text { Pseudomonas fluorescens in a continuous } \\
\text { perfusion environment }\end{array}$ \\
\hline 7 & 2011 & $\begin{array}{l}\text { In vitro } \\
\text { laboratory } \\
\text { experimental }\end{array}$ & $\begin{array}{l}\text { Polymethylmethacrylate } \\
\text { (PMMA) and stainless } \\
\text { steel prostheses }\end{array}$ & $\begin{array}{c}\text { There is no difference between the biomaterials } \\
\text { in biofilm formation by Staphylococcus } \\
\text { epidermidis }\end{array}$ \\
\hline 8 & 2011 & $\begin{array}{l}\text { In vitro } \\
\text { laboratory } \\
\text { experimental }\end{array}$ & $\begin{array}{l}\text { Cobalt-chromium } \\
(\mathrm{Co}-\mathrm{Cr}) \text { ions and particles }\end{array}$ & $\begin{array}{l}\text { There was a reduction on biofilm formation by } \\
\text { Staphylococcus aureus on Co-Cr particles } \\
\text { presence in comparison to metal ions }\end{array}$ \\
\hline 9 & 2012 & $\begin{array}{l}\text { Descriptive } \\
\text { analytical study }\end{array}$ & $\begin{array}{l}\text { Ultrahigh molecular } \\
\text { weight polyethylene, } \\
\text { hydroxyapatite, titanium } \\
\text { alloy and cobalt- } \\
\text { chromium } \\
\text { (Co-Cr) alloy }\end{array}$ & $\begin{array}{c}\text { There is no difference in bacterial adhesion } \\
\text { among distinct biomaterials }\end{array}$ \\
\hline 10 & 2012 & $\begin{array}{c}\text { In vitro } \\
\text { laboratory } \\
\text { experimental }\end{array}$ & $\begin{array}{l}\text { Bioactive gentamicin- } \\
\text { releasing coating }\end{array}$ & $\begin{array}{l}\text { It avoided staphylococcal growth as well as } \\
\text { demonstrated a wide spectrum of antibacterial } \\
\text { activity }\end{array}$ \\
\hline 11 & 2014 & $\begin{array}{l}\text { Descriptive } \\
\text { analytical study }\end{array}$ & $\begin{array}{l}\text { Components of ultrahigh } \\
\text { molecular weight } \\
\text { polyethylene, titanium- } \\
\text { aluminium-niobium } \\
\text { (Ti6Al7Nb) alloy, }\end{array}$ & $\begin{array}{l}\text { Polyethylene presented the highest bacterial } \\
\text { load, followed by ceramic and metal } \\
\text { components }\end{array}$ \\
\hline
\end{tabular}




\begin{tabular}{|c|c|c|c|c|}
\hline & & & $\begin{array}{c}\text { ceramics and pure } \\
\text { titanium }\end{array}$ & \\
\hline 12 & 2015 & $\begin{array}{l}\text { In vitro and in } \\
\text { vivo laboratory } \\
\text { experimental }\end{array}$ & $\begin{array}{c}\text { Biodegradable } \\
\text { gentamicin- } \\
\text { hydroxyapatite coating }\end{array}$ & $\begin{array}{l}\text { Showed antibacterial efficacy similar to } \\
\text { traditional method (cement usage) }\end{array}$ \\
\hline 13 & 2015 & $\begin{array}{c}\text { In vitro } \\
\text { laboratory } \\
\text { experimental }\end{array}$ & $\begin{array}{l}\text { Silver-zirconium } \\
\text { carbonitride } \\
\text { (Ag-ZrCN) coating }\end{array}$ & $\begin{array}{l}\text { Silver activation is responsible for an } \\
\text { antimicrobial effect on } \mathrm{Ag}-\mathrm{ZrCN} \text { coatings }\end{array}$ \\
\hline 14 & 2015 & $\begin{array}{l}\text { In vitro } \\
\text { laboratory } \\
\text { experimental }\end{array}$ & $\begin{array}{c}\text { Cross-linked polyethylene } \\
\text { combined with vitamin E- } \\
\text { blended and a poly(2- } \\
\text { methacryloyloxyethyl } \\
\text { phosphorylcholine) layer } \\
\text { coating } \\
\end{array}$ & $\begin{array}{l}\text { The number of bacteria adhered on biomaterial } \\
\text { surface was reduced by } 100 \text {-fold or more }\end{array}$ \\
\hline 15 & 2016 & $\begin{array}{c}\text { In vitro } \\
\text { laboratory } \\
\text { experimental }\end{array}$ & $\begin{array}{l}\text { Acylase-containing } \\
\text { polyurethane coating }\end{array}$ & It inhibited bacterial growth \\
\hline 16 & 2017 & $\begin{array}{c}\text { In vitro } \\
\text { laboratory } \\
\text { experimental }\end{array}$ & $\begin{array}{l}\text { Tantalum acetabular } \\
\text { component }\end{array}$ & $\begin{array}{l}\text { It did not present antibacterial and antibiofilm } \\
\text { activities }\end{array}$ \\
\hline
\end{tabular}

\begin{tabular}{|c|c|c|}
\hline $\begin{array}{l}\text { Relation between } \\
\text { microorganisms }\end{array}$ & & $\begin{array}{l}\text { developed biomaterials presented wide spectrum of } \\
\text { antibacterial activity (NEUT et al., 2012, 2015). }\end{array}$ \\
\hline
\end{tabular}

Clinical studies that analyzed bacterial adhesion on different joint prosthesis biomaterials evidenced that polyethylene (PE) presented greater number of colony forming units than metallic materials and polymethylmethacrylate (PMMA). Staphylococcus epidermidis and Staphylococcus aureus were isolated on most of joint prosthesis components, being S. epidermidis, Staphylococcus capitis and $S$. aureus the bacteria with the greatest numbers of colony forming units (TOMÁŠ; NACHTNEBL; OTIEPKA, 2007; NURYASTUTI et al., 2011; GÓMEZ-BARRENA et al., 2012; LASS et al., 2014).

\section{Metals and biofilm formation}

Regarding titanium roughness, a study compared biofilm formation on three titanium alloy surfaces with different roughness, since each alloy presented a different surface finish according to certain hip prosthesis region. Results demonstrated that there was a difference in biofilm formation on biomaterials with distinct roughness (RAMAGE et al., 2003). Another studied metal was tantalum, but it did not presented antibiofilm activity in comparison to titanium (HARRISON et al., 2017).

\section{Antibiotic coatings}

Researchers developed a technology to covalently tether vancomycin to titanium without damaging biological properties of the metal surface and with antimicrobial activity (PARVIZI et al., 2004). Other studies with gentamicin and gentamicin-hydroxyapatite coatings showed that the

\section{Ion influence on biofilm formation}

Researchers evaluated how cobaltchromium (Co-Cr) ions could influence on bacterial growth and biofilm formation. 200,000 / 93,000 $\mu \mathrm{g} / \mathrm{L} \mathrm{Co}-\mathrm{Cr}$ concentrations reduced by $15 \%$ biofilm formation in $S$. aureus samples and by $26 \%$ in coagulase-negative Staphylococcus samples. Moreover, images obtained by confocal laser scanning microscopy demonstrated that the ions resulted in a reduction in biofilm thickness of more than 50\% (HOSMAN et al., 2009). Similar study concluded that $\mathrm{Co}-\mathrm{Cr}$ particles presented bacteriostatic activity against $S$. aureus under dynamic growth conditions (HOSMAN et al., 2011).

\section{New coatings with antimicrobial activity}

Various studies were performed to develop and evaluate new coatings with the ability to minimize microbial colonization (PARVIZI et al., 2004; HENRIQUES et al., 2009; LEWIS et al., 2010; NEUT et al., 2012, 2015; FERRERI et al., 2015; KYOMOTO et al., 2015; GROVER et al., 2016). Silver-zirconium carbonitride (Ag- $\mathrm{ZrCN}$ ) thin films and cross-linked polyethylene combined with vitamin E-blended and a poly(2methacryloyloxyethyl phosphorylcholine) layer (HD-CLPE(VE) with PMPC) coatings presented antimicrobial activity (FERRERI et al., 2015; KYOMOTO et al., 2015). Moreover, the biomaterial developed with an acylase-containing polyurethane coating disrupted quorum-sensing signals 
responsible by communication and progression of biofilm formation (GROVER et al., 2016). On the other hand, nanocrystalline diamond coatings did not avoid biofilm development, and titaniumsilicon-carbon-oxygen-nitrogen (Ti-Si-C-O-N) coatings presented lower amount of biofilm (biomass), yet high cytotoxicity (HENRIQUES et al., 2009; LEWIS et al., 2010).

\section{DISCUSSION}

Biomaterials used on hip arthroplasties were researched to identify their possible influence on biofilm formation prevention on hip prosthesis. The presence of factors that interfere on biofilm formation was evidenced: metal roughness, antibiotic coatings action, difference in biofilm adhesion on distinct biomaterials, ions action, different concentrations of titanium and silver, coating activity of HD-CLPE(VE) with PMPC and acylase activity in disrupting quorum-sensing signals (RAMAGE et al., 2003; PARVIZI et al., 2004; TOMÁŠ́; NACHTNEBL; OTIEPKA, 2007; HENRIQUES et al., 2009; HOSMAN et al., 2009, 2011; NURYASTUTI et al., 2011; GÓMEZBARRENA et al., 2012; NEUT et al., 2012, 2015; LASS et al., 2014; FERRERI et al., 2015; KYOMOTO et al., 2015; GROVER et al., 2016).

The biofilm is a complex problem, and its importance is acknowledge by health researchers and professionals. Hence, researchers have intensified efforts to prevent infection associated with prostheses and other medical devices (ARCIOLA et al., 2012).

Among the factors that influence biofilm adhesion, biomaterial composition stands out. In this review, polyethylene was the material with higher biofilm adhesion compared to PMMA and to hip prosthesis metals, once polyethylene components presented the highest microbial load (TOMÁŠ́; NACHTNEBL; OTIEPKA, 2007; NURYASTUTI et al., 2011; GÓMEZ-BARRENA et al., 2012; HOLINKA et al., 2012; LASS et al., 2014). Co-Cr particles and ions released due to friction generated by artificial joint movement were also identified as factors that interfere in biofilm formation, reducing its development (HOSMAN et al., 2009, 2011). However, in another study $\mathrm{Co}-\mathrm{Cr}$ particles allowed bacterial growth in planktonic form (ANWAR et al., 2007).

In scientific literature, development trend of coatings aiming for biofilm formation prevention was evidenced. Among adopted strategies, the antibiotic incorporation in orthopaedic cement used for fixation stands out. However, with the increasing progress in biomaterial models that promote better osseointegration, a technology capable of binding antibiotics to non-cemented prostheses was necessary and was developed. Antibiotic coatings that bind themselves to a metal were developed to provide antimicrobial effect without losing biomaterial properties (PARVIZI et al., 2004; NEUT et al., 2012, 2015).

Moreover, studies evidenced initiatives of production of new biomaterials with antibiofilm activity, but without antibiotic incorporation. This integrative literature review gathered five of this new coatings. Cross-linked polyethylene combined with vitamin E-blended and a poly(2methacryloyloxyethyl phosphorylcholine) layer coatings, silver-zirconium carbonitride (Ag- $\mathrm{ZrCN})$ films, acylase-containing polyurethane coatings and titanium-silicon-carbon-oxygen-nitrogen (Ti-Si-C$\mathrm{O}-\mathrm{N})$ films had antibacterial activity. However, nanocrystalline diamond coatings did not presented the same effect (HENRIQUES et al., 2009; LEWIS et al., 2010; FERRERI et al., 2015; KYOMOTO et al., 2015; GROVER et al., 2016).

Staphylococci are pathogens isolated with higher frequency on prostheses. $S$. epidermidis stood out as the main bacterium that causes infections associated with orthopaedic implants (NABLO; ROTHROCK; SCHOENFISCH, 2005; ARCIOLA et al., 2012). Studies of this review confirmed these results, since the microorganisms that presented the greatest numbers of colony forming units on hip arthroplasties were $S$. epidermidis, $S$. aureus and $S$. capitis (TOMÁŠ́; NACHTNEBL; OTIEPKA, 2007; NURYASTUTI et al., 2011; GÓMEZ-BARRENA et al., 2012; LASS et al., 2014).

The results of this study showed direct applicability in clinical practice because there are gaps in scientific literature about recommendations of antibiofilm agents to be used on orthopaedic prostheses. Besides, it is possible to infer that the choice of a biomaterial with better antibiofilm activity may reduce the risk of infection and loss of implant due to biofilm formation.

Thus, this research presented limitations by restricting articles published in Portuguese, Spanish and English as well as the fact that not all studies reported the calculation or sample randomization. However, the objective of identifying the scientific evidences about biofilm formation prevention on hip prosthesis biomaterials was achieved in this integrative literature review, allowing the progress of knowledge in this field. 


\section{CONCLUSION}

In the scientific literature, the biomaterials that presented properties against biofilm formation were: bioactive gentamicin, biodegradable gentamicin-hydroxyapatite, vancomycin, acylasecontaining polyurethane, cross-linked polyethylene combined with vitamin E-blended and a poly(2methacryloyloxyethyl phosphorylcholine) layer, silver-zirconium carbonitride films and titaniumsilicon-carbon-oxygen-nitrogen films. Moreover, the $\mathrm{Co}-\mathrm{Cr}$ particles released from metallic joint prosthesis showed higher antibiofilm activity than Co-Crions.

\section{ACKNOWLEDGEMENTS}

This study was financed in part by the Coordenação de Aperfeiçoamento de Pessoal de Nível Superior - Brasil (CAPES) - Finance Code 001.

RESUMO: O objetivo deste estudo foi identificar as evidências científicas a respeito da prevenção da formação de biofilme em biomateriais de próteses de quadril. Revisão integrativa da literatura, com vistas a responder a seguinte questão: quais são as evidências científicas a respeito da prevenção da formação de biofilme em biomateriais de próteses de quadril? Realizado no portal PubMed da National Library of Medicine e nas bases: Web of Science, Embase, Cochrane, CINAHL e LILACS. Incluíram-se estudos primários sobre a temática, publicados online até novembro de 2017 em inglês, espanhol e português. Dos 16 estudos primários analisados, 81,25\% foram pesquisas experimentais in vitro; polietileno demonstrou maior contagem de unidades formadoras de colônia do que materiais metálicos e polimetilmetacrilato. Dos estudos clínicos, Staphylococcus epidermidis e Staphylococcus aureus foram isolados na maioria dos componentes das próteses articulares. Novos revestimentos constituídos de poliuretano contendo acilase, filmes de prata-carbonitreto de zircônio, gentamicina bioativa, gentamicina-hidroxiapatita biodegradável, vancomicina, filmes de titânio-silício-carbonooxigênio-nitrogênio e polietileno reticulado combinado com vitamina $E$ e uma camada de poli (2-metacriloiloxietil fosforilcolina) foram desenvolvidos para prevenção da formação de biofilme. Além disso, íons de cobalto-cromo (Co-Cr) inibiram o crescimento bacteriano, e houve uma tendência das partículas de cobalto-cromo diminuírem o desenvolvimento de biofilmes. Os biomateriais que apresentaram propriedades que previnem a formação de biofilme foram: gentamicina bioativa, gentamicina-hidroxiapatita biodegradável, vancomicina, poliuretano contendo acilase, polietileno reticulado combinado com vitamina E e uma camada de poli (2-metacriloiloxietil fosforilcolina), filmes de prata-carbonitreto de zircônio e filmes de titânio-silício-carbono-oxigênio-nitrogênio. Além disso, partículas de Co-Cr liberadas das próteses articulares metálicas mostraram maior atividade antibiofilme que íons de Co-Cr.

PALAVRAS-CHAVE: Biofilmes. Prótese de quadril. Artroplastia de quadril.

\section{REFERENCES}

ANWAR, H. A.; ALDAM, C. H.; VISUVANATHAN, S.; HART, A. J. The effect of metal ions in solution on bacterial growth compared with wear particles from hip replacements. Bone \& Joint Journal, v. 89, n. 12, p. 1655-1659, 2007. Avaible on: https://doi.org/10.1302/0301-620X.89B12.19714. Acessed on: 30 maio 2018.

ARCIOLA, C. R.; CAMPOCCIA, D.; SPEZIALE, P.; MONTANARO, L.; COSTERTON, J. W. Biofilm formation in Staphylococcus implant infections. A review of molecular mechanisms and implications for biofilm-resistant materials. Biomaterials, v. 33, n. 26, p. 5967-5982, 2012. Avaible on: https://doi.org/10.1016/j.biomaterials.2012.05.031. Acessed on: 30 maio 2018.

BOZIC, K. J.; KAMATH, A. F.; ONG, K.; LAU, E.; KURTZ, S.; CHAN, V.; VAIL, T. P.; RUBASH, H.; BERRY, D. J. Comparative epidemiology of revision arthroplasty: failed THA poses greater clinical and economic burdens than failed TKA. Clinical Orthopaedics and Related Research ${ }^{\circledR}$, v. 473, n. 6, p. 21312138, 2015. Avaible on: https://link.springer.com/article/10.1007/s11999-014-4078-8. Acessed on: 30 maio 2018.

BOZIC, K. J.; KURTZ, S. M.; LAU, E.; ONG, K.; VAIL, T. P.; BERRY, D. J. The epidemiology of revision total hip arthroplasty in the United States. The Journal of bone and joint surgery. American volume, v. 91, n. 1, p. 128-133, 2009. Avaible on: 
https://journals.lww.com/jbjsjournal/subjects/Hip/Abstract/2009/01000/The_Epidemiology_of_Revision_Total _Hip.16.aspx. Acessed on: 30 maio 2018.

CAMPOCCIA, D.; MONTANARO, L.; ARCIOLA, C. R. The significance of infection related to orthopedic devices and issues of antibiotic resistance. Biomaterials, v. 27, n. 11, p. 2331-2339, 2006. Avaible on: https://doi.org/10.1016/j.biomaterials.2005.11.044. Acessed on: 30 maio 2018.

DONLAN, R. M. Biofilms and device-associated infections. Emerging infectious diseases, v. 7, n. 2, p. 277, 2001. Avaible on: https://www.ncbi.nlm.nih.gov/pmc/articles/PMC2631701/. Acessed on: 30 maio 2018.

FERRERI, I.; CALDERON, V. S.; GALINDO, R. E.; PALACIO, C.; HENRIQUES, M.; PIEDADE, A. P.; CARVALHO, S. Silver activation on thin films of $\mathrm{Ag}-\mathrm{ZrCN}$ coatings for antimicrobial activity. Materials Science and Engineering: C, v. 55, p. 547-555, 2015. Avaible on: https://doi.org/10.1016/j.msec.2015.05.071. Acessed on: 30 maio 2018.

FRÖJD, V. On $\mathrm{Ca}^{2+}$ incorporation and nanoporosity of titanium surfaces and the effect on implant performance. Thesis - Department of Prosthodontics, Malmö University, Malmö, 2010. Avaible on: http://muep.mau.se/handle/2043/10781. Acessed on: 30 maio 2018.

GÓMEZ-BARRENA, E.; ESTEBAN, J.; MEDEL, F.; MOLINA-MANSO, D.; ORTIZ-PEREZ, A.; CORDERO-AMPUERO, J.; PUÉRTOLAS, J. A. Bacterial adherence to separated modular components in joint prosthesis: a clinical study. Journal of Orthopaedic Research, v. 30, n. 10, p. 1634-1639, 2012. Avaible on: https://doi.org/10.1002/jor.22114. Acessed on: 30 maio 2018.

GROVER, N.; PLAKS, J. G.; SUMMERS, S. R.; CHADO, G. R.; SCHURR, M. J.; KAAR, J. L. Acylase-containing polyurethane coatings with anti-biofilm activity. Biotechnology and bioengineering, $v$. 113, n. 12, p. 2535-2543, 2016. Avaible on: https://doi.org/10.1002/bit.26019. Acessed on: 30 maio 2018.

HARRISON, P. L.; HARRISON, T.; STOCKLEY, I.; SMITH, T. J. Does tantalum exhibit any intrinsic antimicrobial or antibiofilm properties? Bone Joint Journal, v. 99, n. 9, p. 1153-1156, 2017. Avaible on: https://doi.org/10.1302/0301-620X.99B9.BJJ-2016-1309.R1. Acessed on: 30 maio 2018.

HENRIQUES, M.; SUSANO, M.; CARVALHO, I.; FERRERI, I.; CARVALHO, S.; OLIVEIRA, R. Biological properties of Ti-Si-CON thin films. Journal of Nano Research, v. 6, p. 99-114, 2009. Avaible on: https://doi.org/10.4028/www.scientific.net/JNanoR.6.99. Acessed on: 30 maio 2018.

HOLINKA, J.; PILZ, M.; HIRSCHL, A. M.; GRANINGER, W.; WINDHAGER, R.; PRESTERL, E. Differential bacterial load on components of total knee prosthesis in patients with prosthetic joint infection. The International journal of artificial organs, v. 35, n. 10, p. 735-741, 2012. Avaible on: http://journals.sagepub.com/doi/abs/10.5301/ijao.5000152. Acessed on: 30 maio 2018.

HOSMAN, A. H.; VAN DER MEI, H. C.; BULSTRA, S. K.; BUSSCHER, H. J.; NEUT, D. Metal-on-metal bearings in total hip arthroplasties: Influence of cobalt and chromium ions on bacterial growth and biofilm formation. Journal of Biomedical Materials Research Part A, v. 88, n. 3, p. 711-716, 2009. Avaible on: https://doi.org/10.1002/jbm.a.31922. Acessed on: 30 maio 2018.

HOSMAN, A. H.; VAN DER MEI, H. C.; BULSTRA, S. K.; KUIJER, R.; BUSSCHER, H. J.; NEUT, D. Influence of Co-Cr particles and Co-Cr ions on the growth of staphylococcal biofilms. International Journal of Artificial Organs, v. 34, n. 9, p. 759-765, 2011. Avaible on:

http://citeseerx.ist.psu.edu/viewdoc/download?doi=10.1.1.870.1978\&rep=rep1\&type=pdf. Acessed on: 30 maio 2018.

KLOUCHE, S.; SARIALI, E.; MAMOUDY, P. Total hip arthroplasty revision due to infection: a cost analysis approach. Orthopaedics \& Traumatology: Surgery \& Research, v. 96, n. 2, p. 124-132, 2010. Avaible on: https://doi.org/10.1016/j.otsr.2009.11.004. Acessed on: 30 maio 2018. 
KYOMOTO, M.; SHOBUIKE, T.; MORO, T.; YAMANE, S.; TAKATORI, Y.; TANAKA, S.; MIYAMOTO, H.; ISHIHARA, K. Prevention of bacterial adhesion and biofilm formation on a vitamin E-blended, crosslinked polyethylene surface with a poly (2-methacryloyloxyethyl phosphorylcholine) layer. Acta biomaterialia, v. 24, p. 24-34, 2015. Avaible on: https://doi.org/10.1016/j.actbio.2015.05.034. Acessed on: 30 maio 2018.

LAMAGNI, T. Epidemiology and burden of prosthetic joint infections. Journal of Antimicrobial Chemotherapy, v. 69, n. suppl_1, p. i5-i10, 2014. Avaible on: https://doi.org/10.1093/jac/dku247. Acessed on: 30 maio 2018.

LASS, R.; GIUREA, A.; KUBISTA, B.; HIRSCHL, A. M.; GRANINGER, W.; PRESTERL, E.; WINDHAGER, R.; HOLINKA, J. Bacterial adherence to different components of total hip prosthesis in patients with prosthetic joint infection. International orthopaedics, v. 38, n. 8, p. 1597-1602, 2014. Avaible on: https://link.springer.com/article/10.1007/s00264-014-2358-2. Acessed on: 30 maio 2018.

LEONHARDT, A.; OLSSON, J.; DAHLEN, G. Bacterial colonization on titanium, hydroxyapatite, and amalgam surfaces in vivo. Journal of dental research, v. 74, n. 9, p. 1607-1612, 1995. Avaible on: http://journals.sagepub.com/doi/abs/10.1177/00220345950740091701. Acessed on: 30 maio 2018.

LEWIS, J. S.; GITTARD, S. D.; NARAYAN, R. J.; BERRY, C. J.; BRIGMON, R. L.; RAMAMURTI, R.; SINGH, R. N. Assessment of microbial biofilm growth on nanocrystalline diamond in a continuous perfusion environment. Journal of manufacturing science and engineering, v. 132, n. 3, p. 030919, 2010. Avaible on: $\mathrm{http}: / /$ manufacturingscience. asmedigitalcollection. asme.org/article. .aspx? articleid=1457627. Acessed on: 30 maio 2018.

NABLO, B. J.; ROTHROCK, A. R.; SCHOENFISCH, M. H. Nitric oxide-releasing sol-gels as antibacterial coatings for orthopedic implants. Biomaterials, v. 26, p. 917-924, 2005. Avaible on:

https://doi.org/10.1016/j.biomaterials.2004.03.031. Acessed on: 30 maio 2018.

NEUT, D.; DIJKSTRA, R. J.; THOMPSON, J. I.; KAVANAGH, C.; VAN DER MEI, H. C.; BUSSCHER, H. J. A biodegradable gentamicin-hydroxyapatite-coating for infection prophylaxis in cementless hip prostheses. European cells \& materials, v. 2, n. 29, p. 42-55, 2015. Avaible on: http://europepmc.org/abstract/med/25552428. Acessed on: 30 maio 2018.

NEUT, D.; DIJKSTRA, R. J.; THOMPSON, J. I.; VAN DER MEI, H. C.; BUSSCHER, H. J. A gentamicin-releasing coating for cementless hip prostheses - Longitudinal evaluation of efficacy using in vitro bio-optical imaging and its wide-spectrum antibacterial efficacy. Journal of Biomedical Materials Research Part A, v. 100, n. 12, p. 3220-3226, 2012. Avaible on: https://doi.org/10.1002/jbm.a.34258. Acessed on: 30 maio 2018.

NURYASTUTI, T.; KROM, B. P.; AMAN, A. T.; BUSSCHER, H. J.; VAN DER MEI, H. C. Ica-expression and gentamicin susceptibility of Staphylococcus epidermidis biofilm on orthopedic implant biomaterials.

Journal of Biomedical Materials Research Part A, v. 96, n. 2, p. 365-371, 2011. Avaible on: https://doi.org/10.1002/jbm.a.32984. Acessed on: 30 maio 2018.

PARVIZI, J.; WICKSTROM, E.; ZEIGER, A. R.; ADAMS, C. S.; SHAPIRO, I. M.; PURTILL, J. J.; SHARKEY, P. F.; HOZACK, W. J.; ROTHMAN, R. H.; HICKOK, N. J. Frank Stinchfield Award: Titanium Surface with Biologic Activity against Infection. Clinical orthopaedics and related research, v. 429, p. 3338, 2004. Avaible on:

https://journals.lww.com/corr/Abstract/2004/12000/FRANK_STINCHFIELD_AWARD_Titanium_Surface_ with.5.aspx. Acessed on: 30 maio 2018.

PUCKETT, S. D.; TAYLOR, E.; RAIMONDO, T.; WEBSTER, T. J. The relationship between the nanostructure of titanium surfaces and bacterial attachment. Biomaterials, v. 31, n. 4, p. 706-713, 2010. Avaible on: https://doi.org/10.1016/j.biomaterials.2009.09.081. Acessed on: 30 maio 2018. 
RAMAGE, G.; TUNNEY, M. M.; PATRICK, S.; GORMAN, S. P.; NIXON, J. R. Formation of Propionibacterium acnes biofilms on orthopaedic biomaterials and their susceptibility to antimicrobials.

Biomaterials, v. 24, n. 19, p. 3221-3227, 2003. Avaible on: https://doi.org/10.1016/S0142-9612(03)00173-X. Acessed on: 30 maio 2018.

SOUSA, A. F. L.; MARQUES, D. M.; MONTEIRO, R. M.; QUEIROZ, A. A. F. L.; ANDRADE, D.; WATANABE, E. Prevention of biofilm formation on artificial pacemakers: is it feasible? Acta Paulista de Enfermagem, v. 30, n. 6, p. 644-650, 2017. Avaible on: http://dx.doi.org/10.1590/1982-0194201700085. Acessed on: 30 maio 2018.

TOMÁŠ, T.; NACHTNEBL, L.; OTIEPKA, P. The relation between implanted material and infection of the total joint replacement. Orthopaedic Surgery, v. 80, n. 3, p. 107-122, 2007. Avaible on:

http://www.med.muni.cz/biomedjournal/pdf/2007/sm_3.pdf\#page=27. Acessed on: 30 maio 2018.

VON RECUM, A. F. Handbook of biomaterials evaluation: scientific, technical and clinical testing of implant materials. 2. ed. Philadelphia: CRC Press, 1998.

WASELAU, M. Aseptic loosening of titanium-aluminum-vanadium-implants: a possible explanation at the level of clinical, histological and biochemical evaluations; preliminary in vivo study. Thesis - Zentralstelle der Studentenschaft, University of Zurich, Zurich, 2002.

WU, Y.; ZITELLI, J. P.; TENHUISEN, K. S.; YU, X.; LIBERTA, M. R. Differential response of Staphylococci and osteoblasts to varying titanium surface roughness. Biomaterials, v. 32, n. 4, p. 951-960, 2011. Avaible on: https://doi.org/10.1016/j.biomaterials.2010.10.001. Acessed on: 30 maio 2018. 